\title{
First evaluation of MyOcean altimetric data in the Arctic Ocean
}

\author{
Cheng, Yongcun; Andersen, Ole Baltazar; Knudsen, Per
}

\section{Published in:}

Ocean Science Discussions

Link to article, DOI:

10.5194/osd-9-291-2012

Publication date:

2012

Document Version

Publisher's PDF, also known as Version of record

Link back to DTU Orbit

Citation (APA):

Cheng, Y., Andersen, O. B., \& Knudsen, P. (2012). First evaluation of MyOcean altimetric data in the Arctic Ocean. Ocean Science Discussions, 9(1), 291-314. https://doi.org/10.5194/osd-9-291-2012

\section{General rights}

Copyright and moral rights for the publications made accessible in the public portal are retained by the authors and/or other copyright owners and it is a condition of accessing publications that users recognise and abide by the legal requirements associated with these rights.

- Users may download and print one copy of any publication from the public portal for the purpose of private study or research.

- You may not further distribute the material or use it for any profit-making activity or commercial gain

- You may freely distribute the URL identifying the publication in the public portal 


\section{First evaluation of MyOcean altimetric data in the Arctic Ocean}

\section{Y. Cheng, O. B. Andersen, and P. Knudsen}

DTU Space, Technical University of Denmark, Copenhagen, Denmark

Received: 12 January 2012 - Accepted: 15 January 2012 - Published: 24 January 2012

Correspondence to: Y. Cheng (cych@space.dtu.dk)

Published by Copernicus Publications on behalf of the European Geosciences Union.

\section{First evaluation of MyOcean altimetric data in the Arctic Ocean \\ Y. Cheng et al.}

\section{Title Page}

Abstract

Conclusions

Tables

14

4

Back

Full Screen / Esc

Printer-friendly Version

Interactive Discussion 


\section{Abstract}

The MyOcean V2 preliminary (V2p) data set of weekly gridded sea level anomaly (SLA) maps from 1993 to 2009 over the Arctic region is evaluated against existing altimetric data sets and tide gauge data. Compared with DUACS V3.0.0 (Data Unification and

5 Altimeter Combination System) data set, MyOcean V2p data set improves spatial coverage and quality as well as maximum temporal correlation coefficient between altimetry and tide gauge data. The estimated amplitude of sea level annual signal and linear sea level trend from MyOcean data set are evaluated against altimetry from DUACS and RADS (Radar Altimeter Database System), the SODA (Simple Ocean Data Assimilation) ocean reanalysis and tide gauge data sets from PSMSL (Permanent Service for Mean Sea Level). The results show that the MyOcean data set fits in-situ measurements better than DUACS data set with respect to amplitude of annual signal and linear sea level trend. However, the MyOcean V2p data set exhibits an unrealistic large linear sea level trend compared with that from other data sources.

\section{Introduction}

There is a growing concern about how the high latitudes regions will respond to climate change (Prandi et al., 2011). However, obtaining satellite data in high latitude regions is generally very problematic. In the Arctic Ocean (For this investigation defined as $65^{\circ} \mathrm{N}-90^{\circ} \mathrm{N}$ ), the sun-synchronous satellite altimetry measurements are always affected by the presence of sea ice. Consequently, it is difficult to get accurate altimetric data for many topics of oceanography and climatology, such as determining the linear sea level trend over the regions. Alternatively, dedicated efforts have been applied to study the sea level variability over the regions using tide gauge data or local ocean general circulation models (e.g. Pavlov, 2001; Proshutinsky, 2004; Proshutinsky stations are situated at the Norwegian and Russian border and hereby only observing the easternmost part of the Arctic Ocean.

OSD

9, 291-314, 2012

First evaluation of MyOcean altimetric data in the Arctic Ocean

Y. Cheng et al.

\section{Title Page}

\section{Full Screen / Esc}

Printer-friendly Version

Interactive Discussion 
The SLTAC (Sea Level Thematic Assembly) Center within the EU-FP7 (seventh framework program) MyOcean project aims to derive sea level service at European level for GMES (Global Monitoring for Environment and Security) marine applications. This study evaluates these new MyOcean V2 preliminary (V2p) weekly sea level 5 anomaly (SLA) maps from the SLTAC, and compare with alternate altimetric data sets like the SSALTO/DUACS (Ssalto multi-mission ground segment/Data Unification and Altimeter Combination System) global processed delayed time data sets.

The altimetric data taken from RADS (Radar Altimeter Database System), tide gauge data and latest released SODA (Simple Ocean Data Assimilation, V2.2.4, 1993-2008) 10 ocean reanalysis (Giese and Ray, 2011) are also used as independent data for the validation. All the data sets used in this study are introduced in the following section. Results and summary are given in Sects. 3 and 4, respectively.

\section{Data}

\subsection{MyOcean V2p data set}

15 A special effort has been made to reprocess altimetric data in the Arctic Ocean and create user friendly data with the spatial resolution increased to $0.125^{\circ} \times 0.125^{\circ}$ in latitude by longitude. The SLA maps from 887 weeks cover the period from 6 January 1993 to 30 December 2009, which are given relative to the DNSC08 mean sea surface (Andersen and Knudsen, 2009) from multisatellite (i.e. ERS-1, ERS-2 and Envisat) altimetry missions.

In order to show the improvements of data spatial coverage in MyOcean V2p data set, Fig. 1a and $b$ shows the number (in weeks) of the valid data. The comparison of Fig. 1b with 1a demonstrates that the data spatial coverage is extended in the Laptev Sea, the East Siberian Sea, the Beaufort Sea, the Greenland Sea and around the Queen Elizabeth Islands. Especially, it can be seen clearly that the distribution of number of valid data is corrected around Novaya Zemlya. The changing mean sea surface

\section{OSD}

9, 291-314, 2012

First evaluation of MyOcean altimetric data in the Arctic Ocean

Y. Cheng et al.

\section{Title Page}


from CLS01 to DNSC08 is responsible for the extension of data spatial coverage in MyOcean V2p data set. However, presence of sea ice periodically prevents altimeter measurements and the number of valid data is less than 200 weeks over the regions outside $75^{\circ} \mathrm{N}$ parallel in the Laptev Sea, the East Siberian Sea and the Beaufort Sea.

\section{$5 \quad 2.2$ SSALTO/DUACS data set}

The weekly gridded "Upd" SLA maps $\left(0.25^{\circ} \times 0.25^{\circ}\right)$ in delayed time component of SSALTO/DUACS system from 1993 to 2009 are used for the evaluation. "Upd" (for "updated") SLA maps V3.0.0 is distributed by AVISO (Archiving, Validation and Interpretation of Satellite Oceanographic data) with support from CNES (the Centre Na10 tional d'Etudes Spatiales) (http://www.aviso.oceanobs.com/duacs/). Compared it with older DUACS products, the SLA maps coverage is extended at high latitudes using the newer global mean sea level profiles CLS01 (Collecte Localisation Satellites). There is a maximum number of 887 weeks in the Arctic Ocean from DUACS global processed data set, which covers the same period as MyOcean data set.The readers can refer to the SSALTO/DUACS handbook (available from http://www.aviso.oceanobs.com) for more details about the data set processing.

\subsection{RADS data set}

The along-track data from RADS (Radar Altimeter Database System) is available from http://rads.tudelft.nl/rads/. For this evaluation, the $1-\mathrm{Hz}$ altimetric data are based on final Geophysical Data Records (GDRs) products. Multi-satellite research requires consistency, and at present RADS attempts and provides cross-calibrated satellite altimetry and a continuous sea level record, including the identification of numerous instrumental errors, drifts and discontinuities (Leuliette and Scharroo, 2010). The standard state of the art range and geophysical corrections (i.e. the default settings in RADS) are applied to the ERS and Envisat along track altimetric data used in this investigation. The RADS SLAs are given relative to the DNSC08 mean sea surface (Andersen
OSD

9, 291-314, 2012

First evaluation of MyOcean altimetric data in the Arctic

Ocean

Y. Cheng et al.

\section{Title Page}

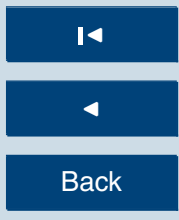


and Knudsen, 2009). Then the data are data are averaged over monthly intervals and processed onto normal rectangular grids of $1^{\circ}$ by $3^{\circ}$ in latitude and longitude to account for trace density. Subsequently, the monthly SLA data are used to estimate amplitude of annual signal and linear sea level trend over the regions.

\section{$5 \quad 2.4$ SODA ocean reanalysis}

In this study the monthly sea level data from latest release of the SODA (V2.2.4) ocean reanalysis (available from http://soda.tamu.edu/assim/) have been used to evaluate amplitude of annual signal and linear sea level trend estimated from MyOcean V2p data set for the 1993-2008 period. The ocean model is based on POP version 2.0.1 10 numerics (Smith et al., 1992) with a horizontal resolution that is on average $0.4^{\circ} \times 0.25^{\circ}$ and with 40 levels in the vertical. Output variables are averaged mapped onto a uniform global $0.5^{\circ} \times 0.5^{\circ}$ horizontal grid using the horizontal grid spherical coordinate remapping and interpolation package of Jones (1999). The ocean model surface boundary conditions, e.g. surface wind stress for the surface momentum fluxes, $10 \mathrm{~m}$ wind speed etc., for computing heat and freshwater fluxes are provided from a new atmospheric data set 20CRv2 (Whitaker et al., 2004; Compo et al., 2006, 2011). The temperature and salinity profile data from the World Ocean Database 2009 (WOD09) (Boyer et al., 2009). The readers can refer to Carton and Giese (2008) and Giese and Ray (2011) for more details about the configuration of the system.

\subsection{Tide gauge data sets}

Two sets of tide gauge data are used to evaluate the MyOcean V2p data set. One is a data set (set A) of hourly values to investigate short term variations in sea level. It consists of hourly sea level observations from 11 tide gauge. The data is available from the UHSLC (University of Hawaii Sea Level Center, http://ilikai.soest.hawaii.edu/). with blue dots in Fig. 2. In order to be coherent with the MyOcean V2p data set, the data are averaged over weekly intervals.

OSD

9, 291-314, 2012

First evaluation of MyOcean altimetric data in the Arctic Ocean

Y. Cheng et al.

Title Page

Abstract Introduction

Conclusions

Tables

References

Figures

14

$\rightarrow 1$

4

Back

Close

Printer-friendly Version

Interactive Discussion 
The second (set $\mathrm{B}$ ) is a monthly data set to evaluate long term changes in annual signal and sea level. It consists of monthly data from 26 tide gauges (available from the Permanent Service for Mean Sea Level, http://www.psmsl.org/). The data set is used to determine the amplitude of annual signal and linear sea level trend and compare 5 with that from altimetric data sets.

To be consistent with all altimetric data sets, the dynamic atmospheric corrections (Pascual et al., 2008) are applied to the two data sets. This correction is produced by CLS Space Oceanography Division using the Mog2D model (Carrère and Lyard, 2003) from Legos and distributed by AVISO with support from CNES 10 (http://www.aviso.oceanobs.com/). For the same reasons, the effects of GIA (Glacial Isostatic Adjustment) are not corrected for tide gauge data.

\section{Results}

\subsection{Sea level variance}

The calculated SLA variance is one of the key indicators when evaluating the quality 15

Of satellite altimetric data. Figure 3 illustrates the SLA variance from the MyOcean and DUACS altimetric data sets. Comparing Fig. $3 \mathrm{~b}$ with $3 \mathrm{a}$, we can see the similar pattern of SLA variance from DUACS and MyOcean data sets. In Fig. 3, higher SLA variance (larger than $100 \mathrm{~cm}^{2}$ ) can be seen along the Russian coastline and the highest SLA variance (larger than $350 \mathrm{~cm}^{2}$ ) exists in the East Siberian Sea. Some large signal is also seen in the Hudson Bay, but this Bay is technically not a part of the Arctic Ocean and not mentioned hereafter (i.e. around $65^{\circ} \mathrm{N}-71^{\circ} \mathrm{N}, 84.5^{\circ} \mathrm{W}-70^{\circ} \mathrm{W}$ ). As for MyOcean data set (Fig. 3b), slightly higher SLA variance is found over the coastal regions, especially over the coastal regions of the Barents Sea and the Kara Sea. Moreover, the SLA variance is larger than $100 \mathrm{~cm}^{2}$ around the Queen Elizabeth Islands
OSD

9, 291-314, 2012

First evaluation of MyOcean altimetric data in the Arctic Ocean

Y. Cheng et al.

Title Page

Abstract Introduction

Conclusions

References

Tables Figures

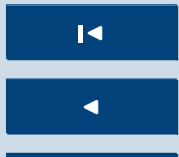

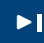

Back

Close

Printer-friendly Version

Interactive Discussion 
The zonal averaged difference in SLA variance between DUACS global processed and MyOcean Arctic is shown in Fig. 4. The MyOcean data set clearly has higher zonally averaged SLA variance, particularly along the coastal regions and around the Queen Elizabeth Islands, which means the quality of the data set is even worse over 5 these regions. The MyOcean data set requires further improvements, especially over the regions with high zonally averaged SLA variance peaks (e.g. around $66^{\circ} \mathrm{N}, 73^{\circ} \mathrm{N}$ and $76^{\circ} \mathrm{N}$ parallel in Fig. 4). In totally, the averaged SLA variances of $63.8 \mathrm{~cm}^{2}$ and $79.5 \mathrm{~cm}^{2}$ are obtained from DUACS and MyOcean Arctic data sets over the Arctic Ocean (e.g. $\left.65^{\circ} \mathrm{N}-82^{\circ} \mathrm{N}\right)$, respectively.

\subsection{Intra-annual sea level signal}

In order to evaluate the intra-annual signal in a comparison with tide gauge data set A, we calculated the temporal correlation coefficient between tide gauge and altimetry SLA time series at each gridded point. The maximum temporal correlation coefficients between all selected tide gauges in the Arctic Ocean and satellite altimetric data are ficient between altimetry data and tide gauge data at Prudhoe Bay (Plus in Fig. 5). For illustration purposes, the regions where the temporal correlation coefficients less than 0.05 have been marked with gray color. Comparison of Fig. $5 \mathrm{~b}$ with $5 \mathrm{a}$ shows a higher temporal correlation coefficient near the tide gauge as one would expect. The maxi20 mum temporal correlation coefficients of 0.78 and 0.87 are obtained between altimetry and tide gauge data from DUACS and MyOcean data sets, respectively. The DUACS shows a dubious low temporal correlation coefficient relatively near to the tide gauge (Fig. $5 \mathrm{a}$, around $140^{\circ} \mathrm{W}-150^{\circ} \mathrm{W}, 71^{\circ} \mathrm{N}$ ) which is most likely a consequence of bad or missing altimetric data. This situation has been improved significantly in the MyOcean 25 data set (Fig. 5b).

The RMSd in Table 2 denote Root Mean Square difference between collocated tide gauge and altimetric data. The data is out of considered if the difference between them is larger than $15 \mathrm{~cm}$. To illustrate where the MyOcean data provides improvement
OSD

9, 291-314, 2012

First evaluation of MyOcean altimetric data in the Arctic Ocean

Y. Cheng et al.

Title Page 
over the older DUACS, the higher maximum temporal correlation coefficent and lower RMSd for each tide gauge between the two different altimetric data sets are bolded and underlined.

The results in Table 2 illustrate that MyOcean data set generally presents equivalent 5 or higher maximum temporal correlation coefficent than DUACS data set with higher RMSd in the Greenland Sea and the Norweigian Sea (tide gauge 1-5 in Table 2). At Vardo (tide gauge located in the Barents Sea), Illulissat and Sisimiut (tide gauge located in the Buffin Bay), higher RMSd is obtained from MyOcean data set than that from DUACS data set. A slightly higher SLA variance from MyOcean data set (Fig. 3b) 10 than that from DUACS data set (Fig. 3a) in coastal regions of the Barents Sea and the Buffin Bay accounts for the difference. The calculated mean maximum temporal correaltion coefficent with tide gauge implies that generally the MyOcean data set improved compared with the DUACS data set.

\subsection{The annual signal}

15 The annual signal in the Arctic Ocean is larger than $10 \mathrm{~cm}$ along the Russian coastline (Cheng and Andersen, 2011). Hence, the amplitude of annual signal estimated from MyOcean data set is evaluated against that estimated from other altimetric data sets, SODA ocean reanalysis and monthly tide gauge data (i.e. tide gauge data set B). Figure $6 \mathrm{a}$ and $\mathrm{b}$ illustrates the amplitudes of annual signal estimated from DUACS and 20 MyOcean data sets, respectively. Comparison of Fig. 6b with $6 \mathrm{a}$ shows the significant annual signal (larger than $9 \mathrm{~cm}$ ) along large part of the shallow regions along the Russian coastline, which is also present in the Beaufort Sea and around Elizabeth Islands (Fig. 2b). The questionable large amplitude of annual signal in the East Siberian Sea and the Laptev Sea in Fig. 6a for DUACS is reduced in Fig. 6b for the MyOcean.

25 In Fig. 6c, the amplitude of annual signal from SODA shows higher amplitude of annual signal along the Russian coastline than that from altimetric data. The inverse barometer correction is not applied to SODA reanalysis results, which is one of the main contributors to the difference. Figure $6 \mathrm{~d}$ is the annual signal from model DTU10ANN

\section{OSD}

$9,291-314,2012$

First evaluation of MyOcean altimetric data in the Arctic Ocean

Y. Cheng et al.

\section{Title Page}

\section{4}

Back

Close
Full Screen / Esc

Printer-friendly Version

Interactive Discussion 
(cited from Cheng and Andersen, 2011) with the inverse barometer correction applied. Comparing the annual signal from DTU10ANN (Fig. 6d) with that from altimetric data (Fig. 6a and b), we can see the significant decrease of the annual signal amplitude in the Laptev Sea, the East Siberian Sea and around Elizabeth Islands. The percentage 5 of data availability and the quality of MyOcean data set over the regions are linked with the difference. Moreover, the coherent patterns of amplitude of annual signal are found in the Norwegian Sea from all data sources.

For illustration purposes, the amplitudes of annual signal from monthly tide gauge data are also presented in Fig. $6 a$ and $b$ with same color scale, respectively. The po10 sitions of tide gauges are marked with pluses. High amplitude $(10-11 \mathrm{~cm})$ of annual signal is found in the East Siberian Sea. To show the difference between altimetry and tide gauge data, Fig. 7 illustrates the comparison of annual signal between altimetry and tide gauge data. Compared with the amplitude of annual signal at all tide gauges, the RMSd of $5.03 \mathrm{~cm}$ and $4.04 \mathrm{~cm}$ are obtained for DUACS and MyOcean SLA 15 products, respectively. The mean difference between altimetry and tide gauge derived amplitude of annual signal are $1.09 \mathrm{~cm}$ and $-0.19 \mathrm{~cm}$ for DUACS and MyOcean data sets, respectively, which demonstrates MyOcean data set fits in situ measurements better in amplitude of annual signal than DUACS data set.

\subsection{Inter-annual sea level change}

20 It is important to map the inter-annual sea level changes for studies of climate change as accurate as possible. From the 17 year sea level record in the Arctic Ocean the linear sea level trend is estimated from MyOcean data set. Figure 8 along with the estimate from different data sources, it shows that the MyOcean data set presents highest linear sea level trend, especially in the Beaufort Sea, where is also shown from

25 the SODA ocean reanalysis. The mean sea level trends of $1.8 \mathrm{~mm} \mathrm{yr}^{-1}, 3.7 \mathrm{~mm} \mathrm{yr}^{-1}$, $0.9 \mathrm{~mm} \mathrm{yr}^{-1}$ and $0.4 \mathrm{~mm} \mathrm{yr}^{-1}$ are obtained from DUACS, MyOcean, RADS and SODA data sets over the region $\left(65^{\circ} \mathrm{N}-82^{\circ} \mathrm{N}, 180^{\circ} \mathrm{E}-180^{\circ} \mathrm{W}\right)$, respectively, which have been weighted by the cosine latitude. The mean sea level trend of $3.9 \mathrm{~mm} \mathrm{yr}^{-1}$ is obtained
OSD

9, 291-314, 2012

First evaluation of MyOcean altimetric data in the Arctic Ocean

Y. Cheng et al.

Title Page 
from tide gauge data. It agrees the results from MyOcean data set better than that from other data sources. Moreover, the sea level trend from tide gauges are also presented in the plots with same color scale and the pluses denote their positions. it can be seen from Fig. 8 that the sea level trend determined from tide gauge data agree with that 5 from MyOcean data set (Fig. 8b) best in the Laptev Sea and the East Siberian Sea.

It should be kept in mind that the averaged numbers given above depends on the selected region. Especially the high sea level trend in the Beaufort Sea (Fig. 8b) affects the determined mean sea level trend significantly. In order to perform an independent comparison where all models have full coverage, we calculated the mean sea 10 level trend over the region $\left(30^{\circ} \mathrm{W}-100^{\circ} \mathrm{E}, 65^{\circ} \mathrm{N}-82^{\circ} \mathrm{N}\right)$. The mean sea level trend of $2.3 \mathrm{~mm} \mathrm{yr}^{-1}, 3.2 \mathrm{~mm} \mathrm{yr}^{-1}, 2.2 \mathrm{~mm} \mathrm{yr}^{-1}$ and $0.7 \mathrm{~mm} \mathrm{yr}^{-1}$ are obtained from DUACS, MyOcean, RADS and SODA data sets over the regions, respectively. The mean sea level trend of $2.2 \mathrm{~mm} \mathrm{yr}^{-1}$ obtained from tide gauge data shows better agreement with the results from RADS.

15 Figure 9 illustrates the comparison of collocated sea level trend between that from altimetry and tide gauge data. The RMSd of $4.97 \mathrm{~mm} \mathrm{yr}^{-1}$ and $4.26 \mathrm{~mm} \mathrm{yr}^{-1}$ are obtained for DUACS and MyOcean data sets, respectively. The mean differences between altimetry and tide gauge data derived sea level trend are $-1.54 \mathrm{~mm} \mathrm{yr}^{-1}$ and $-1.45 \mathrm{~mm} \mathrm{yr}^{-1}$ for DUACS and MyOcean SLA products, respectively, which implies the sea level trend at tide gauges is overestimated from MyOcean altimetric data and the new reprocessed SLA products agree with in situ measurements better than the global processing SLA products. We also investigate the effects of GIA correction on the evaluation. The same conclusions are made if GIA correction applied to altimetry and tide gauge data.

\section{Summary}

This study evaluating the preliminary MyOcean V2p data set against DUACS, RADS, SODA and tide gauge data sets. The MyOcean reprocessed data set shows improved

\section{OSD}

9, 291-314, 2012

First evaluation of MyOcean altimetric data in the Arctic Ocean

Y. Cheng et al.

\section{Title Page}

\section{4}


spatial coverage in a comparison with other contemporary data sets (e.g. DUACS global processed data set). One of the reasons being that it applied the DNSC08 mean sea surface model which has complete coverage in the Arctic.

The MyOcean reprocessed data set shows better agreement with in situ measure5 ment on intra annual to annual scales than DUACS data set but has problems with trend estimation. It is shows higher linear sea level trend than that from other data sources (DUACS, SODA, RADS and tide gauges). Magnitude of difference in linear sea level trend between MyOcean data set and other data sets is high and requires further investigation, especially in the Beaufort Sea. It needs to be further improved 10 in the Laptev Sea, the East Siberian Sea and around the Elizabeth Islands due to the unrealistic high SLA variance in these regions.

Acknowledgements. The research is a contribution to the project "MyOcean", which is granted by the European Commission within the GMES Program (7th Framework Program). We thank the RADS team for providing altimetric data. The SODA team is acknowledged. We thank

15 RADS (Radar Altimeter Database System) for providing altimetry data, PSMSL (Permanent Service for Mean Sea Level) and UHSLC (University of Hawaii Sea Level Center) for providing tide gauge data.

\section{References}

Andersen, O. B. and Knudsen, P.: DNSC08 mean sea surface and mean dynamic topography 20

Boyer, T. P., Antonov, J. I., Baranova, O. K., Garcia, H. E., Johnson, D. R., Locarnini, R. A., Mishonov, A. V., Seidov, D., Smolyar, I. V., and Zweng, M. M.: World ocean database, NOAA Atlas NESDIS, vol. 66, edited by: Levitus, S., 216 pp., DVDs, US Govt. Print. Off., Washington, D.C., 2009.

25 Carrère, L. and Lyard, F.: Modeling the barotropic response of the global ocean to atmospheric wind and pressure forcing - comparisons with observations, Geophys. Res. Lett., 30, 12751278, doi:10.1029/2002GL016473, 2003.

\section{OSD}

9, 291-314, 2012

First evaluation of MyOcean altimetric data in the Arctic Ocean

Y. Cheng et al.

\section{Title Page}


Carton, J. and Giese, B. S.: A Reanalysis of Ocean Climate Using Simple Ocean Data Assimilation (SODA), Mon. Weather Rev., 136, 2999-3017, doi:10.1175/2007MWR1978.1, 2008.

Cheng, Y. and Andersen, O. B.: Multimission empirical ocean tide modeling for shallow waters and polar seas, J. Geophys. Res., 116, 1-11, doi:10.1029/2011JC007172, 2011.

5 Compo, G. P., Whitaker, J. S., and Sardeshmukh, P. D.: Feasibility of a 100 year reanalysis using only surface pressure data, B. Am. Meteorol. Soc., 87, 175-190, 2006.

Compo, G. P., Whitaker, J. S., Sardeshmukh, P. D., Matsui, N., Allan, R. J., Yin, X., Gleason, B. E., Vose, R. S., Rutledge, G., Bessemoulin, P., Brönnimann, S., Brunet, M., Crouthamel, R. I., Grant, A. N., Groisman, P. Y., Jones, P. D., Kruk, M. C., Kruger, A. C., Marshall, G. J., Maugeri, M., Mok, H. Y., Nordli, Ø., Ross, T. F., Trigo, R. M., Wang, X., L., Woodruff, S. D., and Worley, S. J.: The Twentieth Century Reanalysis Project, Q. J. Roy. Meteorol. Soc., 137, 1-28, doi:10.1002/qj.776, 2011.

Giese, B. S. and Ray, S.: El Niño variability in simple ocean data assimilation (SODA), 18712008, J. Geophys. Res., 116, 1-17, doi:10.1029/2010JC006695, 2011.

15 Jones, P. W.: First- and second-order conservative remapping schemes for grids in spherical coordinates, Mon. Weather Rev., 127, 2204-2210, doi:10.1175/15200493(1999) $127<2204: F A S O C R>2.0 . C O ; 2,1999$.

Leuliette, E. and Scharroo, R.: Integrating Jason-2 into a Multiple-Altimeter Climate Data Record, Marine Geodesy, 33, 504-517, doi:10.1080/01490419.2010.487795, 2010.

Pascual, A., Marcos, M., and Gomis, D.: Comparing the sea level response to pressure and wind forcing of two barotropic models: Validation with tide gauge and altimetry data, J. Geophys. Res., 113, C07011, doi:10.1029/2007JC004459, 2008.

Pavlov, V.: Seasonal and long term sea level variability in the marginal seas of the Arctic Ocean, Polar Research, 20, 153-160, 2001.

Prandi, P., Ablain, M., Picot, N., and Cazenave, A.: Sea level in the Arctic Ocean from satellite altimetry, CryoSat Validation Workshop, ESA/ESRIN, Frascati, Italy, 1-3 February 2011.

Proshutinsky, A.: Secular sea level change in the Russian sector of the Arctic Ocean, J. Geophys. Res., 109, 1-19, doi:10.1029/2003JC002007, 2004.

Proshutinsky, A., Ashik, I., Häkkinen, S., Hunke, E., Krishfield, R., Maltrud, M., Maslowski, W., and Zhang, J.: Sea level variability in the Arctic Ocean from AOMIP models, J. Geophys. Res., 112, 1-25, doi:10.1029/2006JC003916, 2007.

Smith, R. D., Dukowicz, J. K., and Malone, R. C.: Parallel ocean general circulation modeling, Physica D, 60, 38-61, doi:10.1016/0167-2789(92)90225-C, 1992.
OSD

$9,291-314,2012$

First evaluation of MyOcean altimetric data in the Arctic Ocean

Y. Cheng et al.

Title Page

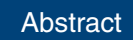

Introduction

Conclusions

References

Tables

Figures

14

4

Back

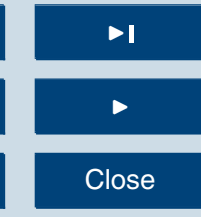

Full Screen / Esc

Printer-friendly Version

Interactive Discussion 
Whitaker, J. S., Compo, G. P., Wei, X., and Hamill, T. M.: Reanalysis without radiosondes using ensemble data assimilation, Mon. Weather Rev., 132, 1190-1200, 2004.

\section{OSD}

9, 291-314, 2012

First evaluation of MyOcean altimetric data in the Arctic Ocean

Y. Cheng et al.

Title Page

Abstract

Introduction

Conclusions

References

Tables

Figures

14

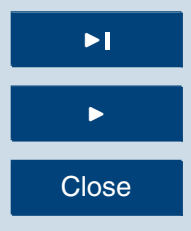

Back

Full Screen / Esc

Printer-friendly Version

Interactive Discussion 


\section{OSD}

9, 291-314, 2012

First evaluation of MyOcean altimetric data in the Arctic Ocean

Table 1. Information about tide gauge data set A used in this study.

\begin{tabular}{llrrc}
\hline \multicolumn{1}{r}{ Station } & & Latitude $\left(^{\circ}\right)$ & Longitude $\left(^{\circ}\right)$ & Time span \\
\hline 1. Ammassalik & (AMMA) & 65.50 & -37.00 & Sep 1991-Dec 1998 \\
2. Andenes & (ANDE) & 69.32 & 16.15 & Oct 1991-Dec 2003 \\
3. Honningsvarg & (HONN) & 70.98 & 25.98 & Jan 2001-Mar 2011 \\
4. Ny-Alesund & (NYAL) & 78.93 & 11.95 & Aug 1976-Dec 2003 \\
5. Rorvik & (RORV) & 64.87 & 11.25 & Aug 1969-Dec 2003 \\
6. Scoresbysund & (SCOR) & 70.48 & -21.98 & Oct 2007-Apr 2011 \\
7. Vardo & (VARD) & 70.34 & 31.03 & Sep 1947-Dec 2003 \\
8. Ilulissat & (ILUL) & 69.22 & -51.10 & Jul 1992-Jun 1997 \\
9. Nome AK & (NOME) & 64.50 & -165.43 & Oct 1992-Dec 2008 \\
10. Prudhoe Bay & (PRUD) & 70.39 & -148.51 & Jun 1993-Nov 2008 \\
11. Sisimiut & (SISI) & 66.93 & -53.67 & Sep 1991-Dec 1998 \\
\hline
\end{tabular}

Interactive Discussion

Title Page

Abstract Introduction

Conclusions

References

Tables Figures
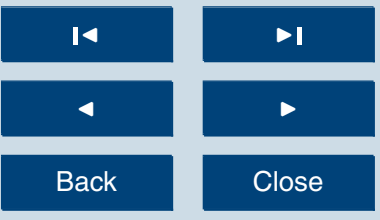

Full Screen / Esc

Printer-friendly Version 


\section{OSD}

9, 291-314, 2012

Table 2. The maximum temporal correlation coefficient between tide gauge and altimetric data for each tide gauge. The RMSd denote the Root Mean Square difference (RMSd, $\mathrm{cm}$ ) between collocated tide gauge and altimetric data in the Arctic Ocean.

\begin{tabular}{|c|c|c|c|c|}
\hline \multirow{2}{*}{ Station } & \multicolumn{2}{|l|}{ DUACS } & \multicolumn{2}{|l|}{ MyOcean } \\
\hline & $\begin{array}{c}\text { Temporal correlation } \\
\text { coefficients }(\%)\end{array}$ & $\begin{array}{l}\text { RMSd } \\
(\mathrm{cm})\end{array}$ & $\begin{array}{l}\text { Temporal correlation } \\
\text { coefficients }(\%)\end{array}$ & $\begin{array}{l}\text { RMSd } \\
(\mathrm{cm})\end{array}$ \\
\hline 1. Ammassalik & 57.76 & $\underline{7.65}$ & 61.41 & 7.73 \\
\hline 2. Andenes & 86.66 & $\overline{7.17}$ & $\overline{85.55}$ & 8.64 \\
\hline 3. Honningsvarg & 89.59 & $\overline{7.69}$ & 88.35 & 9.50 \\
\hline 4. Ny-Alesund & $\overline{68.98}$ & $\overline{6.16}$ & 74.19 & 8.08 \\
\hline 5. Rorvik & 85.80 & $\overline{7.23}$ & $\overline{88.16}$ & 8.64 \\
\hline 6. Scoresbysund & 54.74 & $\overline{8.38}$ & $\overline{57.43}$ & $\underline{7.61}$ \\
\hline 7. Vardo & 85.99 & $\underline{7.76}$ & $\overline{80.71}$ & $\overline{8.51}$ \\
\hline 8. Ilulissat & $\overline{78.67}$ & $\overline{4.99}$ & 68.50 & 6.90 \\
\hline 9. Nome & $\overline{85.65}$ & $\overline{8.03}$ & 86.60 & 7.69 \\
\hline 10. Prudhoe Bay & 77.59 & 8.85 & $\overline{87.42}$ & $\overline{8.64}$ \\
\hline 11. Sisimiut & 83.98 & $\underline{5.54}$ & 84.00 & $\overline{8.62}$ \\
\hline Mean & 77.76 & $\underline{7.22}$ & $\underline{78.50}$ & 8.23 \\
\hline
\end{tabular}

First evaluation of MyOcean altimetric data in the Arctic Ocean

Y. Cheng et al.

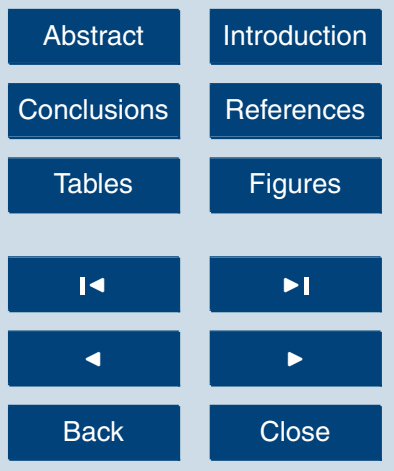

Full Screen / Esc

Printer-friendly Version

Interactive Discussion 


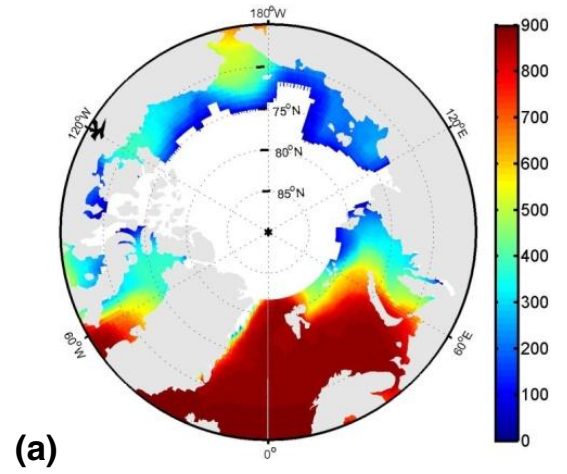

(b)

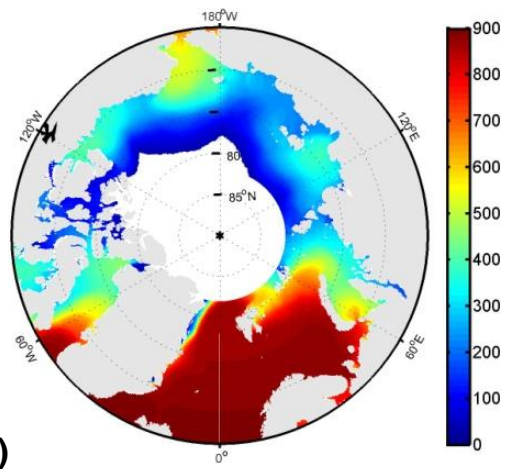

Fig. 1. The number (in weeks) of the valid data in the Arctic Ocean from (a) DUACS data set and (b) MyOcean V2p data set.

\section{OSD}

9, 291-314, 2012

First evaluation of MyOcean altimetric data in the Arctic Ocean

\section{Y. Cheng et al.}

\section{Title Page}

Abstract

Introduction

Conclusions

References

Tables

Figures

14

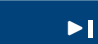

Back

Full Screen / Esc

Printer-friendly Version

Interactive Discussion 


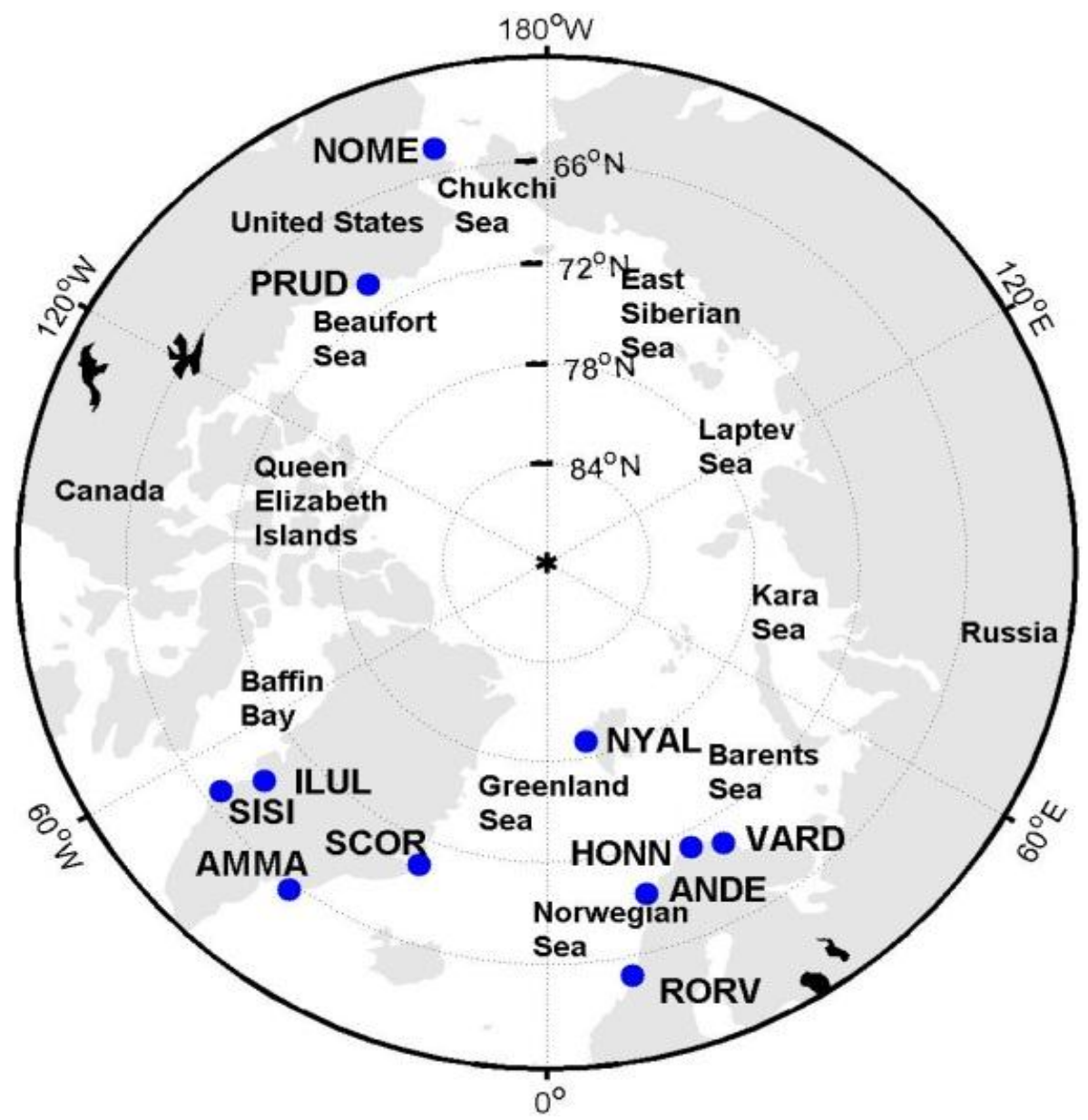

Fig. 2. Locations of the hourly tide gauge data from University of Hawaii Sea Level Center.

OSD

9, 291-314, 2012

First evaluation of MyOcean altimetric data in the Arctic Ocean

\section{Y. Cheng et al.}

Title Page

Abstract

Conclusions

Tables

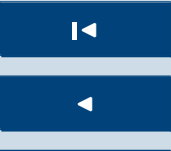

Back

Full Screen / Esc

Printer-friendly Version

Interactive Discussion
Figures

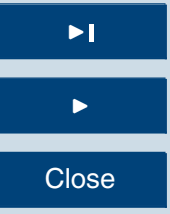




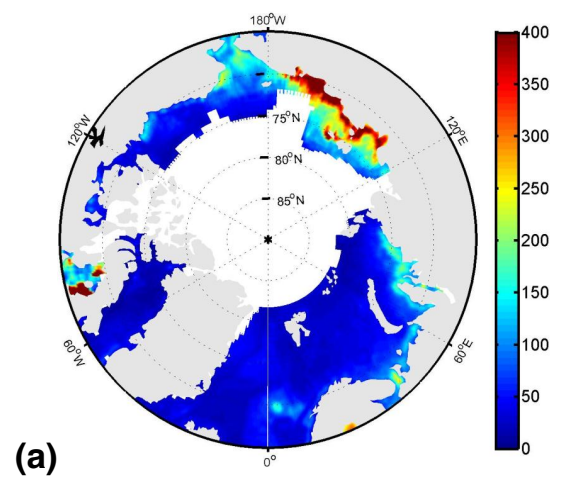

(b)

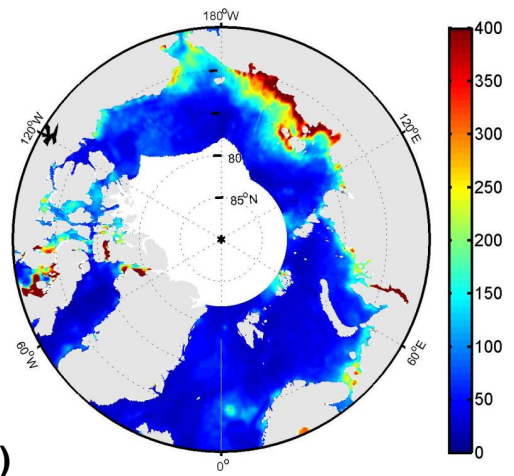

Fig. 3. SLA variance $\left(\mathrm{cm}^{2}\right)$ in the Arctic Ocean from (a) DUACS data set and (b) MyOcean V2p data set. The same color scale is used for all plates.
OSD

9, 291-314, 2012

First evaluation of MyOcean altimetric data in the Arctic Ocean

\section{Y. Cheng et al.}

\section{Title Page}

Abstract

Introduction

Conclusions

References

Tables

Figures

14

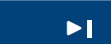

4

Back

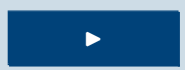

Full Screen / Esc

Printer-friendly Version

Interactive Discussion 


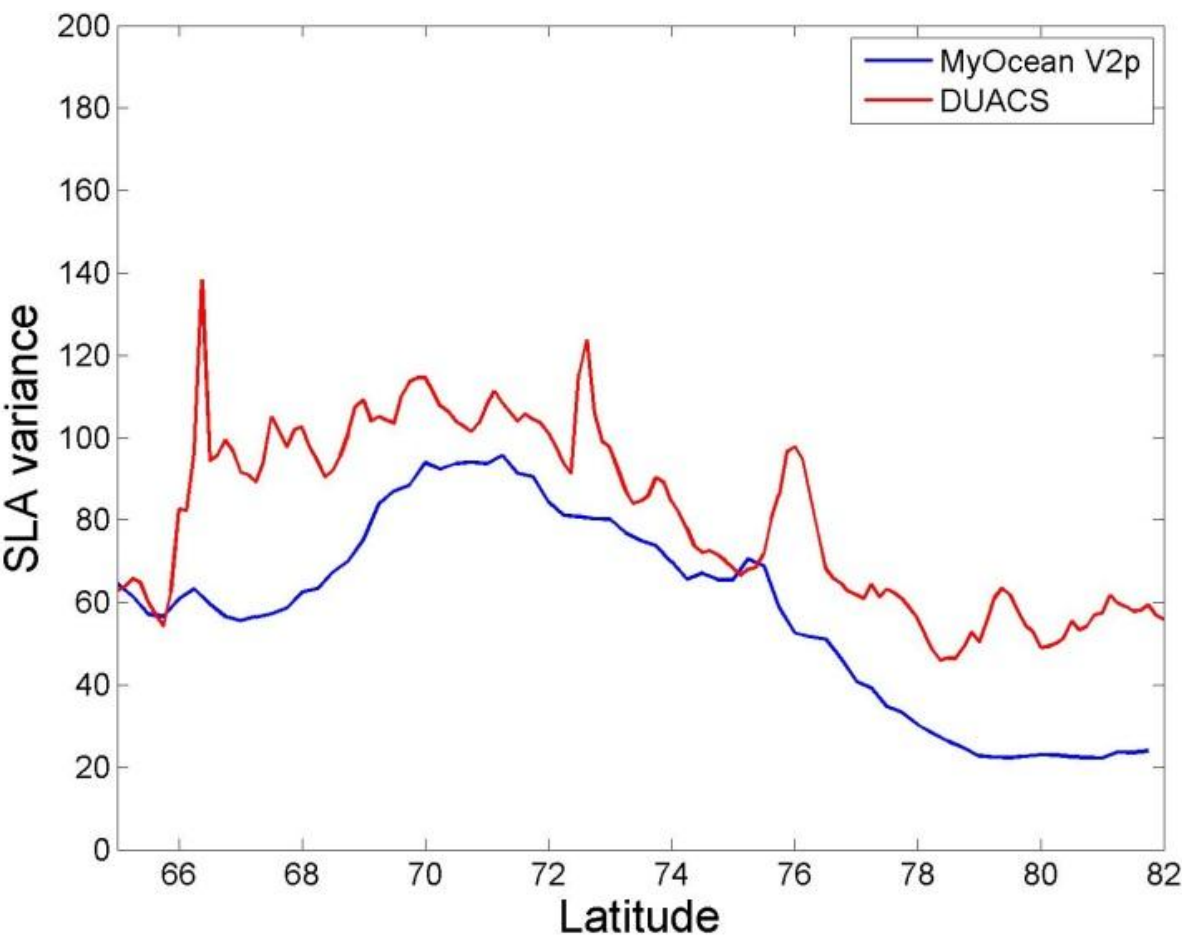

Fig. 4. Zonally averaged SLA variance $\left(\mathrm{cm}^{2}\right)$ from DUACS (blue curve) and MyOcean (red curve) data sets.
OSD

9, 291-314, 2012

First evaluation of MyOcean altimetric data in the Arctic Ocean

\section{Y. Cheng et al.}

Title Page

Abstract

Introduction

Conclusions

References

Tables

Figures

14

4

Back

Close

Full Screen / Esc

Printer-friendly Version

Interactive Discussion 


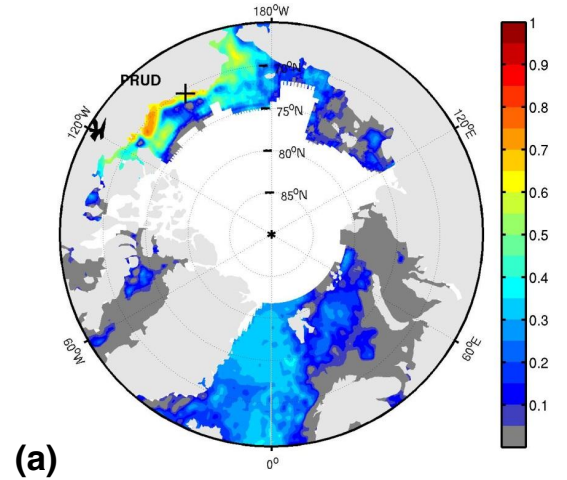

(b)

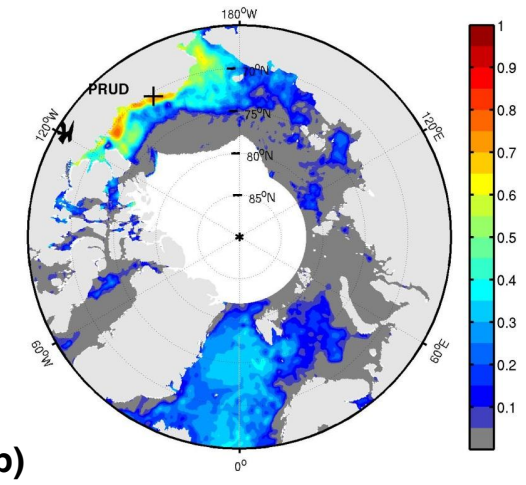

Fig. 5. Spatial distribution of temporal correlation coefficent between tide gauge and altimetric data at Prudhoe Bay: (a) DUACS data set, (b) MyOcean V2p data set. The same color scale is used for all plates.

\section{OSD}

9, 291-314, 2012

First evaluation of MyOcean altimetric data in the Arctic Ocean

\section{Y. Cheng et al.}

\section{Title Page}

Abstract Introduction

Conclusions

References

Tables

Figures

14

$\Delta$

4

Back

Close

Full Screen / Esc

Printer-friendly Version

Interactive Discussion 
(a)

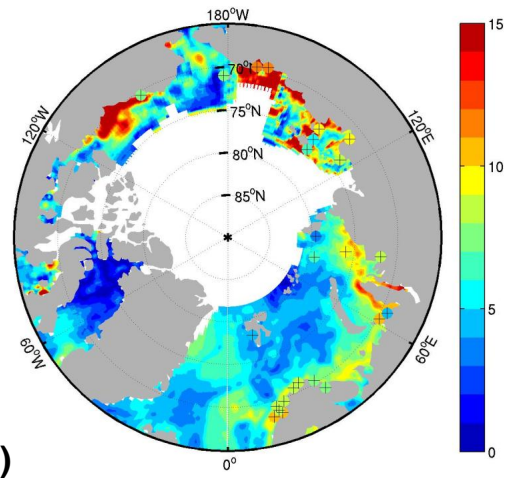

(c)

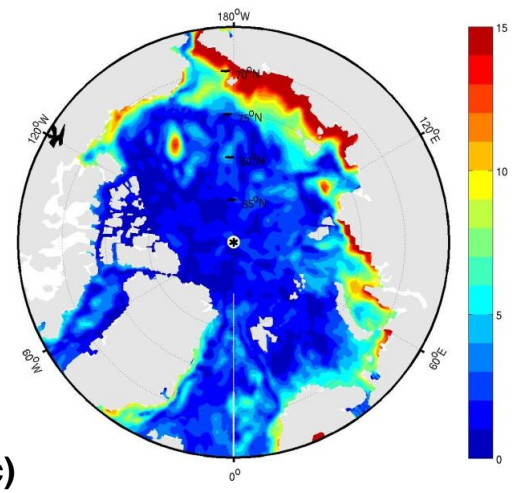

(b)

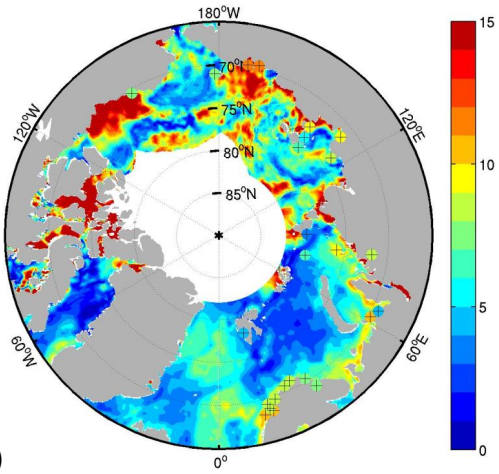

(d)

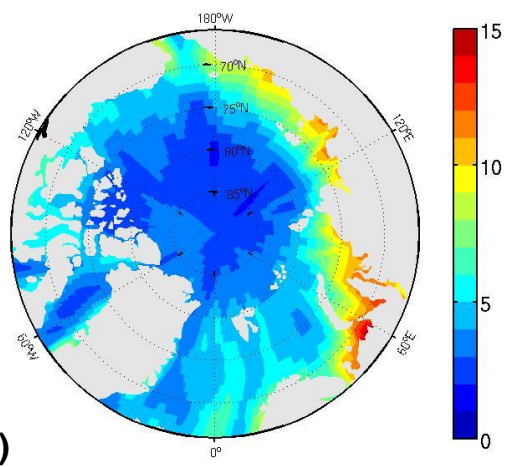

Fig. 6. Spatial distribution of amplitude of annual signal $(\mathrm{cm})$ estiamted from: (a) DUACS data set, (b) MyOcean V2p data set, (c) SODA and (d) DTU10ANN. The same color scale is used for all plates. The pluses in panels (a) and (b) denote the positions of the selected tide gauges.

OSD

9, 291-314, 2012

First evaluation of MyOcean altimetric data in the Arctic Ocean

Y. Cheng et al.

Title Page

Abstract

Conclusions

Tables

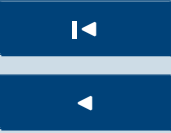

Back

Full Screen / Esc

Printer-friendly Version

Interactive Discussion 
OSD

9, 291-314, 2012

First evaluation of MyOcean altimetric data in the Arctic Ocean (a)

Fig. 7. Comparision between collocated amplitude of annual signal $(\mathrm{cm})$ from altimetry and (b)

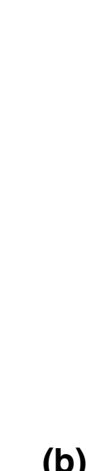

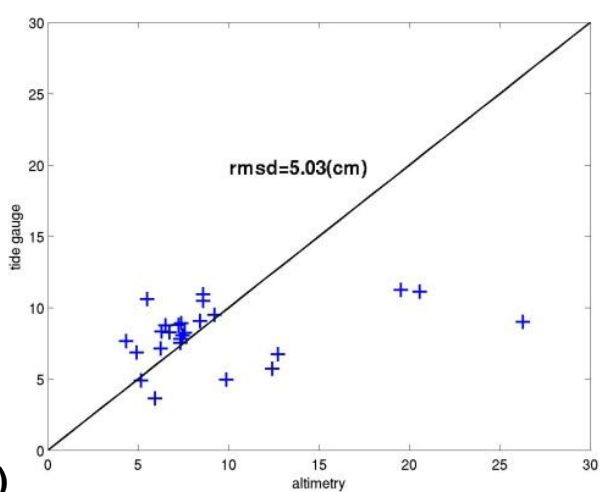

tide gauge data: (a) DUACS data set, (b) MyOcean V2p data set.

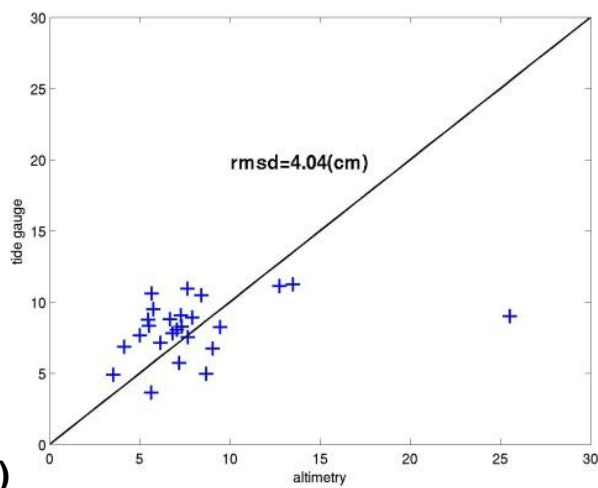

Printer-friendly Version

Interactive Discussion
Abstract

Introduction

Conclusions

Tables

Figures

14

4

Back

Close

Full Screen / Esc 


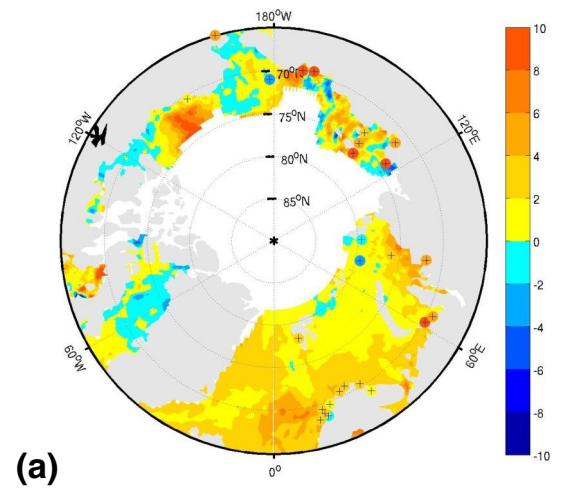

(b)

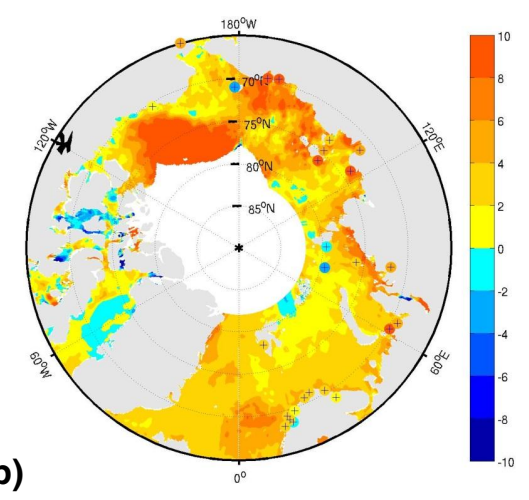

(d)

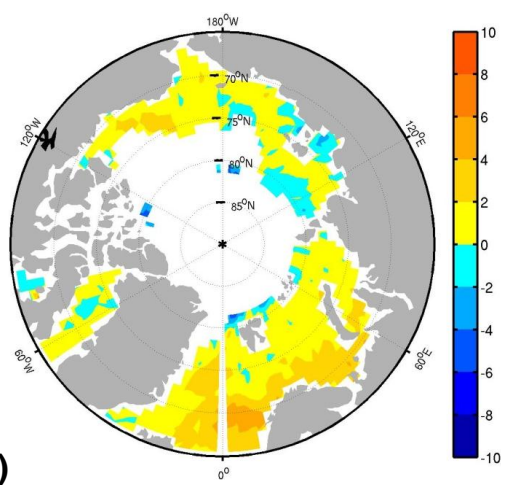

(c)

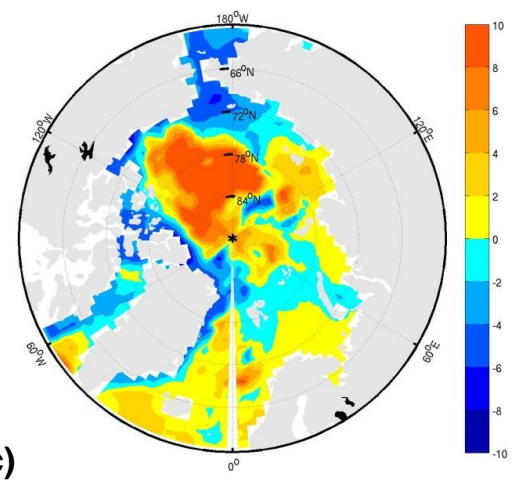

Fig. 8. Sptial distribution of sea level trend $\left(\mathrm{mm} \mathrm{yr}^{-1}\right)$ from: (a) DUACS data set (1993-2009), (b) MyOcean V2p data set (1993-2009), (c) SODA (1993-2008) and (d) RADS (1993-2009). The same color scale is used for all plates. The amplitude of annual signal from tide gauge data (1993-2009) is illustrated in panels (a) and (b) with the same color scale. The pluses in panels (a) and (b) denote the positions of the selected tide gauges.

\section{OSD}

9, 291-314, 2012

First evaluation of MyOcean altimetric data in the Arctic Ocean

\section{Y. Cheng et al.}

Title Page

Abstract

Introduction

Conclusions

References

Tables

Figures

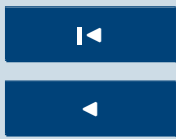

$\rightarrow 1$

Back

$\triangleright$

Close

Full Screen / Esc

Printer-friendly Version

Interactive Discussion 
OSD

9, 291-314, 2012

First evaluation of MyOcean altimetric data in the Arctic Ocean
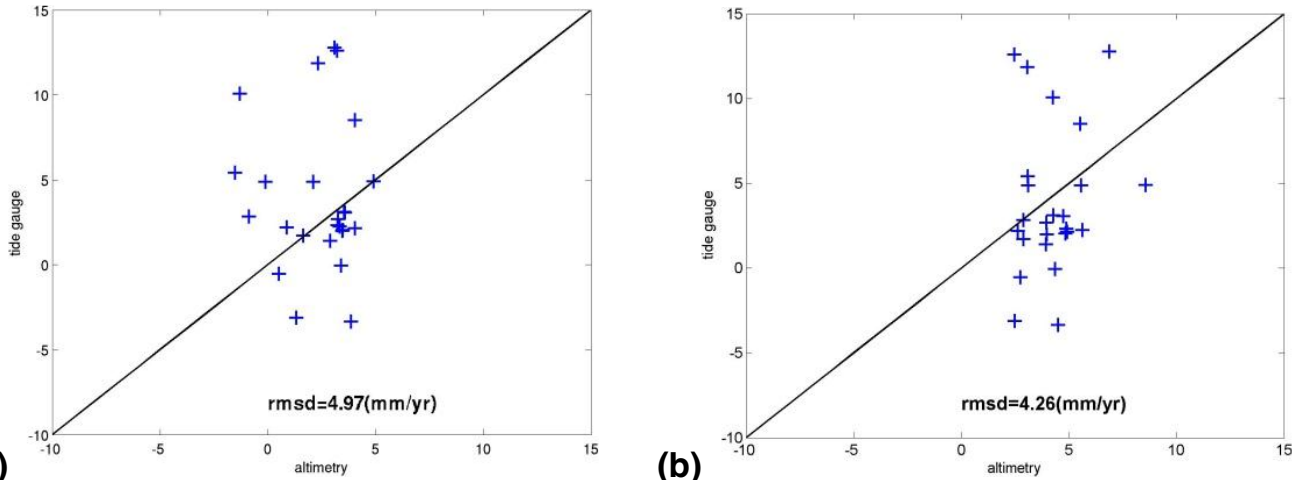

(b) metry
Fig. 9. Comparision between collocated sea level trend $\left(\mathrm{mm} \mathrm{yr}^{-1}\right)$ from tide gauge and altimetric: (a) DUACS data set, (b) MyOcean V2p data set.

\section{Ocean}

Y. Cheng et al.

Title Page

Abstract

Introduction

Conclusions

References

Tables

Figures

14

4

Back

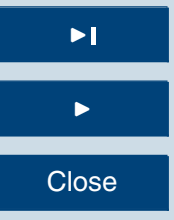

Full Screen / Esc

Printer-friendly Version

Interactive Discussion 